\title{
The Construction and Exploration of the Hierarchical Innovation and Entrepreneurship Education System in Colleges and Universities*
}

\author{
Ya Chen \\ University of Electronic Science and Technology of China \\ Chengdu, China
}

Mingsheng Cao

University of Electronic Science and Technology of China Chengdu, China

\author{
Chunwei Lou** \\ University of Electronic Science and Technology of China \\ Chengdu, China \\ **Corresponding Author \\ Xuhong $\mathrm{Wu}$ \\ University of Electronic Science and Technology of China \\ Chengdu, China
}

\begin{abstract}
The construction of an innovative country poses an urgent need for innovative talents. The development needs of higher education also make innovation and entrepreneurship education reform imperative. By analyzing the main problems faced by China's innovation and entrepreneurship education at the present stage, this paper clarifies the orientation of innovation and entrepreneurship education, proposes a solution for the whole process of innovation and entrepreneurship education system combining with work practices, and realizes the overall process of construction and practical exploration on the innovation and entrepreneurship education model.
\end{abstract}

Keywords-innovation and entrepreneurship education; the hierarchy type; the whole process

\section{INTRODUCTION}

\section{A. The Construction of College Students' Innovation and Entrepreneurship Education System Is the Demand of National Strategic Development.}

The report of the 18th National Congress of the Communist Party of China proposed to implement an innovation-driven development strategy, and the construction of innovative countries put forward new requirements for innovative talents. [2015] No. 32 Document "Opinions of the state council on policies and measures to vigorously promote mass entrepreneurship and innovation" issued by the Chinese government proposes that "1 promoting mass entrepreneurship and innovation" is the source of development, the way to enrich the people, the fairness, and the power. The policy is of great significance for promoting economic restructuring, creating new engines for development, enhancing new development momentum,

*Project: Ideological and Political Education Research Center Project for college students in Sichuan 2016 "Investigation on the Ideological and Political Education Status of College Students in University of Electronic Science and Technology of China", Project No.: CSZ16011 and taking the road of innovation-driven development. "Promoting "mass entrepreneurship and innovation" has become an important way and carrier to promote China's economic development. It has become a general consensus of the whole society to cultivate innovative talents for the construction of innovative countries through innovation and entrepreneurship education.

\section{B. Construction of College Students' Innovation and \\ Entrepreneurship Education System Is the Self- development Need of Higher Education}

The most fundamental task of higher education is talent cultivation, which should provide talent support for national construction and economic development. China's higher education is a complex systematic project, and its sustainable development should also include the expansion of personnel training and the improvement of quality. The innovation of higher education should focus on the key points, improve step by step, combine with point and plane, explore courageously, and make key breakthroughs. The state has included innovation and entrepreneurship education in the "Outline of National Medium- and LongTerm Education Reform and Development Plan", and called for reform of the innovation and entrepreneurship education to promote the reform of the talent training model, and promote colleges and universities to change their focuses from student knowledge learning to student ability and quality improvement so as to improve the soft power of students and the quality of talent training. Innovation and entrepreneurship education reform is an opportunity for the transformation of higher education development and a pioneer and test for the transformation of higher education. 


\section{ThE MAIN PROBLEMS EXISTING IN THE INNOVATION AND ENTREPRENEURSHIP EDUCATION IN CHINA}

\section{A. Without Academic Support, It Has High Professional Pressure}

Specialization is the basic requirement for the cultivation of talents in colleges and universities and the basic premise for enhancing education quality. Some scholars pointed out: "Entrepreneurial education has not yet obtained an independent academic status. Entrepreneurship or entrepreneurship education set up by individual universities is only included in secondary disciplines such as technical economics and enterprise management. It is difficult for this kind of academic status to support the long-term development of entrepreneurship education in colleges and universities. "2 Innovative and entrepreneurial education in colleges and universities is generally separated from the professional education system. Most universities do not incorporate innovation and entrepreneurship education into the discipline planning framework and talent training system, and the faculty structure is incomplete. The curriculum planning is also limited to the spread of scattered knowledge and the innovation and entrepreneurial activities scattered with second class.

\section{B. Social Disputes Are Big, and Ideas Cannot Be Unified}

The general phenomenon of low success rate of college students' entrepreneurship and poor persistence of college students' entrepreneurial projects has made the social controversy of large-scale innovation and entrepreneurship education more and fiercer. In both society and colleges, innovation and entrepreneurship are the practice of the minority. The concept of innovation and entrepreneurship education in colleges and universities believes that innovation and entrepreneurship education is a crash course education of entrepreneur, quality education or career choice education. The utilitarian positioning of society and colleges for innovation and entrepreneurship education also affects the value judgment of college students, so that the students who accept the innovation and entrepreneurship education only stay at the level of general business activities, eager for quick success and instant benefits and they can only see the short-term benefits of entrepreneurial activity. However, the essence and value of innovation and entrepreneurship focus more on quality improvement and ability training.

\section{There Is No Experience to Follow, so They Adopt Copinism}

In 1999, in order to alleviate the pressure of enrollment expansion and solve the employment pressure, China encouraged graduate students to start their own business. It experienced the stage of entrepreneurship education from 2007 to 2009 of promoting employment through entrepreneurship and cultivating entrepreneurial ability, and transformed into the present stage of innovation and entrepreneurship education that implementing innovationdriven development and cultivating innovative and entrepreneurial talents. After nearly 20 years of development, from passive selection to active development, take-ism of China's "innovation and entrepreneurship education model" (that is, copying the successful innovation and entrepreneurship model education in the United States) is different because of the basic national conditions, educational background and economic development stage. In the case that the state has a large number of demands for innovative and entrepreneurial talents, higher education needs to explore the training mode of innovative and entrepreneurial talents with Chinese characteristics in combination with the actual situation of education in China. China's innovation and entrepreneurship education has not officially entered the talent training program. The education system and curriculum are not yet perfect, relying more on temporary secondary classroom arrangements such as competitions and projects.

\section{INNOVATION AND ENTREPRENEURSHIP EDUCATION SYSTEM CONSTRUCTION}

\section{A. Making Clear the Orientation of Innovation and Entrepreneurship Education}

Li Jiahua puts forward that the non-utilitarian strategic goal of innovation and entrepreneurship education is to enable educatees to have entrepreneurial awareness, entrepreneurial personality psychological quality and entrepreneurial ability so as to adapt to social development and change, instead of taking post vocational training as a connotation or crash entrepreneur as a guide.

Innovation and entrepreneurship education should be distinguished from educational orientation of quality education, career planning education, and entrepreneurial crush education. Students' innovative spirit, entrepreneurial awareness and innovation and entrepreneurship ability and the stimulation of students' innovation and entrepreneurship genes are the core objectives of innovation and entrepreneurship education.

Document No. 36 [2015] that "innovation and entrepreneurship education should follow the principles of "face to all, classified training, combining specialty and intensive practice training. "Face to all and classified teaching" points out that it not only should carry out innovation and entrepreneurship popularize education for all students, but also provide personalized guidance education for different groups of students; "combination of specialty" should fully explore the professional characteristics and innovative characteristics of different disciplines, combine the professional characteristics, integrate the innovation and entrepreneurship education with the specialty education, offer integration course, and promote the mutual learning of discipline knowledge and theory and the cultivation of innovation ability; "intensive practice" points out that innovation and entrepreneurship education is the education model of "practice in learning, and learning in practice", and practice and cultivating should be emphasized in all aspects of education. In the exploration of innovation and entrepreneurship education reform, colleges and universities should emphasize diversity, integrate innovation and entrepreneurship education into the talent training system 
based on their own characteristics and advantages, and promote the reform of innovation and entrepreneurship education in an all-round way from the aspects of education system design and support system construction to form distinctive and diverse innovation and entrepreneurship education models.

\section{B. The Hierarchical Process of Innovation and Entrepreneurship Education System Design}

Colleges and universities should integrate innovation and entrepreneurship education into the general framework of talent cultivation in order to cultivate students' innovative spirit, entrepreneurial awareness and innovation and entrepreneurship capability and stimulate students' innovation and entrepreneurship genes as well as carry out innovation and entrepreneurship education system design according to the growth characteristics and development needs of students at different stages. Colleges carry out innovation and entrepreneurship and popularize education for all students, transfer knowledge and cultivate innovation spirit and entrepreneurial awareness, and realize the full coverage of college students' innovation and entrepreneurship education through multi-path class. Colleges should implement innovative entrepreneurship practice education on students with a strong interest in innovation and entrepreneurship, and train and improve students' innovation and entrepreneurship through the implementation of second class entrepreneurship competition and college students' innovation and entrepreneurship projects. For potential students, it should implement innovative and entrepreneurial incubation education, and provide the support of various resources including teachers and venues to enhance the success rate of college students' innovation and entrepreneurship. According to different students, it should construct the pyramid education system including universal education, practical education and incubation education, combining theory with practice and paying equal attention to education popularization and elite training to promote the cultivation of students' innovation and entrepreneurship ability.

1) Explorations on multi-level popularizing education: Classroom teaching is the main way to implement talent training in colleges and universities as well as the main method of students' knowledge learning. Relying on the first classroom to implement the innovation and entrepreneurship popularization education so as to realize the cultivation of students' knowledge system and the awareness of innovation and entrepreneurship, arouse the students' subjective consciousness and stimulate students' innovation and entrepreneurial genes. Universal education is mainly achieved through the integration of innovative and entrepreneurial general education, professional education and innovation and entrepreneurship education.

a) Innovative entrepreneurship general education: General education is a personalized education that fosters students' open thinking, erudition and perfection. The combination of arts and sciences can help students build a comprehensive knowledge structure and ensure the overall development of students. General education is mainly carried out in the lower grades. The college students in admission stage are flexible in thinking and have a strong desire for knowledge. They are in the period of value shaping and forming learning habits. The innovation and entrepreneurship education at this stage should focus on inspiring students' spirit of innovation and cultivating entrepreneurial awareness in order to urge students to develop the habits and concepts of innovative entrepreneurship learning. Innovative and entrepreneurial general education achieves students' innovation and entrepreneurship general education coverage rate of $100 \%$ mainly through the establishment of the "Innovation and Entrepreneurship Foundation" general education courses and MOOC learning and setting requirements for compulsory and elective credits . In addition, in student enrollment education stage, second classroom activities such as the lectures, salons, innovation and entrepreneurship show week can achieve $100 \%$ of the enrollment innovation and entrepreneurial sense education for freshman.

b) Promoting the integration of professional education and innovation and entrepreneurship education: Professional education is highly specialized, highly targeted, and highly systematic. It is an important way for college students to acquire a complete knowledge structure and training discipline thinking. The basic knowledge and theoretical system of professional education is the basis and foundation for the generation of students' innovative spirit and entrepreneurial ability. Through the integration of professional education and innovation and entrepreneurship education, the latest theories of scientific frontier, industrial development and interdisciplinary research will be introduced into professional classrooms in time. It also can motivate the student innovation gene and promote the cultivation of students' innovation and entrepreneurship ability combined with the dual needs of professional knowledge structure construction and innovation and entrepreneurship training and creating interdisciplinary professional curriculum groups.

The integration of professional education and innovation and entrepreneurship education is mainly achieved by professional curriculum reform and discipline competition curriculum. By digging out the systematic characteristics of innovative training such as innovation traits and discipline competitions of different professional knowledge, integrating the basic knowledge popularization of innovation, entrepreneurship education and professional education with internship and practical training, and offering interdisciplinary courses. In this way, a series of progressive and scientific special courses for innovation and entrepreneurship education are established and the mutual promotion of subject knowledge learning and innovation ability is realized.

2) Progressive practice education training: Practical education is an important way to cultivate students' innovative consciousness and improve students' practical ability combining theory with practice through experimental 
teaching, engineering training and other methods. Innovative entrepreneurship practice education is aimed at students who have a strong interest in innovation and entrepreneurship. Through systematic innovation thinking training, comprehensive operational ability and research ability training, students' innovation ability training and entrepreneurship basic training are realized. The implementation mainly relies on the second class discipline competition and cultivation of innovative entrepreneurship projects.

The development of discipline competitions such as robot competitions and electronic design competitions guides students to apply theory to practice, conduct innovative practical training combined with the characteristics of disciplines, and comprehensively enhance their ability of systematic thinking and innovation in knowledge application and practice training. Through the organization of entrepreneurial competitions such as the "Internet +" College Students Innovation and Entrepreneurship Competition and the Youth College Entrepreneurship Competition, entrepreneurship trainings including identification of entrepreneurial opportunity, business model design, investment and financing docking are systematic developed, which promote students' entrepreneurial ability training. Through the support of the University's Innovation and Entrepreneurship Training Program and other projects, the services such as systematic training courses, project diagnosis and consultation, and roadshow guidance are provided, project cultivation and project feasibility are demonstrated, students are guided to start business and enhance the ability of innovation and entrepreneurship.

3) Incubation education and cultivation: College students lack entrepreneurial psychological preparation, core technical support, and skills and experience, etc.. It leads to that the success rate of college students' entrepreneurship in China is only $2 \%-3 \%$. The construction of whole-process innovation and entrepreneurship education system enables students to experience self-selection and passive screening through the process of universal education and practical education. The students who participate in incubation education are already elite students with excellent comprehensive quality.

In the incubation education, the "1+1+1" incubation education breeding model, that is, entrepreneurial incubation model of a student team + an instructor + a research team's entrepreneurial incubation model, and the participation of the instructor and research teams conduct personalized in-depth guidance and resource support for student entrepreneurship program, carry out project incubation, and improve the success rate of student entrepreneurship.

\section{Support System Construction}

The implementation of whole-process innovation and entrepreneurship education model needs a complete support system for entrepreneurship education, mainly involving three aspects: institutions, teachers and resources.

1) Institutional guarantee: The integration of innovation and entrepreneurship education into the whole process of talent cultivation requires a special organization to provide one-stop service and overall resource support for the implementation of innovation and entrepreneurship education and self-employed students. At this stage, most colleges and universities' innovation and entrepreneurship education is implemented by the administrative department or employment department, which sets obstacles for its full implementation. Colleges and universities should set up specialized innovation and entrepreneurship education implementation institutions, and complete supporting infrastructure and institutional guarantees such as related discipline construction, teaching management, and student status management to ensure the normal implementation of innovation and entrepreneurship education.

2) Teachers guarantee: Innovation and entrepreneurship is a multidisciplinary and integrated discipline that requires collaboration and cooperation from teachers of different disciplines. At this stage, the source of innovation and entrepreneurship faculty is single in China. More teachers come from management disciplines and employment guidance departments, and the faculty lacks diversity. The construction of innovative and entrepreneurial faculty is the key to the successful implementation of innovation and entrepreneurship education. According to the different implementation stages of whole-process innovation and entrepreneurship education, the teachers of innovation and entrepreneurship education are mainly divided into three types: theoretical teachers, practical teachers and comprehensive teachers.

The theoretical teachers mainly rely on the first classroom to impart the basic knowledge of innovation and entrepreneurship in the popular education stage. The teachers mainly derive from the college teachers engaged in basic education of innovation and entrepreneurship. The practical teachers mainly rely on the practice education, and carries out innovation ability training and entrepreneurial practice consultation through discipline competition, entrepreneurial competition and project cultivation. The teachers mainly come from college professional teachers and social entrepreneurs. The comprehensive teachers mainly rely on the incubation education and combine the advantages of the postgraduate research team to guide students to practice innovation and entrepreneurship. Teachers are mainly from the school scientific research team and entrepreneurs with practical experience in entrepreneurship.

3) Resource guarantee: The government mainly provides policy support systems and financial support for innovation and entrepreneurship education. It supports college innovation and entrepreneurship activities through the in-depth implementation of undergraduate entrepreneurship guidance program, the formulation of 
support policies for college students' entrepreneurship, and encouragement of establishing entrepreneurial venture funds through various forms.

Schools and enterprises actively explore new modes of cooperation and carry out production and learning cooperation according to the different characteristics of different stages of innovation and entrepreneurship education. Through the measures such as actively promoting the construction of students' innovation and entrepreneurship practice bases, providing talents and project support for innovation and entrepreneurship education, funding the establishment of educational research centers or setting up entrepreneurial teacher positions, it actively participates in innovation and entrepreneurship education.

The cooperation gives full play to the role of university student Science Park and incubator, and provides all-round college student innovation and entrepreneurship service. It also constructs an on-campus incubator to provide venues, equipment and other hardware facilities and necessary entrepreneurial guidance for students' innovation and entrepreneurship practices. It gives full play to the role of a bridge linking between universities and society, explores off-campus incubator resources, establishes college students' entrepreneurial service stations, and provides college students with entrepreneurial consulting, legal consulting, policy consulting and other all-round entrepreneurial services.

As an important resource for the sustainable development of colleges and universities, alumni resources also play an important role in the innovation and entrepreneurship support system. Among them, there are many entrepreneurial alumni and excellent entrepreneurs in top management. Alumni resources can not only strengthen the cooperation between schools and enterprises, but also serve as an important human resource. It can promote the development of innovation and entrepreneurship education by providing entrepreneurial risk funds, conducting entrepreneurship project counseling, and providing entrepreneurial hardware resources.

\section{CONCLUSION}

This paper deeply analyzes the significance of innovation and entrepreneurship education implementation in China, analyzes the main problems of innovation and entrepreneurship education at the present stage, and summarizes the construction ideas of college-level innovation and entrepreneurship education system combining with the practice of innovation and entrepreneurship education in colleges and universities. Innovative and entrepreneurial education should grasp the connotation of innovation and entrepreneurship education according to the characteristics of the school and the different stages of the students, teach students in accordance with their aptitude, and expand resources and carry out innovation and entrepreneurship education exploration according to the target of innovation and entrepreneurship education.

\section{REFERENCES}

[1] "Opinions on policies and measures to vigorously promote mass entrepreneurship and innovation" issued by the state council [J]. Chinese Talents, 2015(13): 5.

[2] Yang Xiaohui. Research on Entrepreneurship Education and Innovative Talents Cultivation in Colleges and Universities in China [J]. China Higher Education Research, 2015(01): 39-44.

[3] Cao Jianhui, Zhou Hebing, Luo Yifan. The Mode of College Students' Innovation and Entrepreneurship Education [J]. Laboratory Research and Exploration, 2010,29(08):195-198.

[4] Qian Jun. Research on the Interactive Fusion Mode of Innovation and Entrepreneurship Education and Professional Education in Colleges and Universities [J]. Education Exploration,2016(11):84-87. 